A RCHIWA, BIBLIOTEKI

I MUZEA KOŚCIELNE 109 (2018)

https://doi.org/10.31743/abmk.2018.109.13

KS. PIOTR LASOTA* - LUBLIN

\title{
MEDYTACYJNE PRZEDSTAWIENIA BOGA W TWÓRCZOŚCI J. KIRKA RICHARDSA
}

W 1999 r. św. Jan Paweł II skierował do artystów następujące wezwanie:

Jaka jest różnica między «stwórcą» a «twórcą»? Ten, kto stwarza, daje samo istnienie, wydobywa coś z nicości - ex nihilo sui et subiecti, (...) i ten ściśle określony sposób działania jest właściwy wyłącznie Wszechmogącemu. Twórca natomiast wykorzystuje coś, co już istnieje i czemu on nadaje formę i znaczenie. Taki sposób działania jest właściwy człowiekowi jako obrazowi Boga. Biblia bowiem stwierdza, że Bóg stworzył mężczyznę i kobietę «na swój obraz» (por. Rdz 1,27), po czym dodaje, że powierzył im misję panowania nad ziemią (por. Rdz 1,28). Było to w ostatnim dniu stworzenia (por. Rdz 1, 28-31). W ciągu poprzednich dni Jahwe stwarzał wszechświat jak gdyby w rytmie kosmicznej ewolucji. Na końcu stworzył człowieka jako najdoskonalszy owoc swego zamysłu. Jemu to poddał widzialny świat niczym ogromne pole, na którym może wyrażać swoje twórcze zdolności ${ }^{1}$.

Ten tok rozumowania pozwala dociec, dlaczego wśród artystów są osoby, które na przykład przez sztukę malarską wewnętrznie pragną przybliżać widzom prawdę o Bogu czy wyjaśniać im prawdy wiary.

W środowiskach nie tylko katolickich, ale również protestanckich czy innych wyznań chrześcijańskich, niewielu jest artystów zajmujących się malowaniem wydarzeń biblijnych czy przedstawień Jezusa. Takich, którzy nie tworzą kiczu sakralnego czy dzieł dewocyjnych, lecz malowidła pozwalające niejako ,spotkać się" z żywym Bogiem przez słowo i obraz ${ }^{2}$. Jednym z nich jest amerykański malarz

* Ks. Piotr Lasota - mgr teologii; doktorant w Instytucie Historii Sztuki KUL; e-mail: petroslasota@gmail.com

${ }^{1}$ Jan Paweł II, List apostolski Ojca Świętego Jana Pawła II do artystów. Do tych, którzy z pasją i poświęceniem poszukują nowych , epifanii” Piękna, aby podarować je światu w twórczości artystycznej, Wrocław 2005, s. 2-3; zob. K. Wojtyła, Ewangelia a sztuka. Rekolekcje dla artystów, Kraków-Rzym 2011, s. 70; G. Ravasi, M.I. Rupnik, Fascynacja pięknem. miedzy Biblia a teologia, thum. Barbara Żurowska, Kraków 2012, s. 88-89.

${ }^{2}$ Dla środowiska katolickiego sztandarowym współczesnym malarzem łączącym medytację Słowa Bożego z obrazem, jest niemiecki ksiądz Sieger Köder (1925-2015). Zob. S. Köder, Die Bibel 
J. Kirk Richards urodzony w 1976 r. w Stanach Zjednoczonych, w mieście Provo w stanie Utah. Wychowywał się i wzrastał w rodzinie mormonów3. W obszarze zainteresowań malarskich dużo miejsca poświęca sztuce współczesnej o tematyce religijnej, w szczególności judeo-chrześcijańskiej. Najbardziej znany jest ze swoich wykładów w Brigham Young University Museum of Art, organizując stale zajęcia i wystawy mające na celu ukazywać życie Chrystusa w słowie i obrazie. Jest autorem ilustracji nie tylko do kilku mormońskich publikacji ${ }^{4}$. Do tej pory wydał następujące cykle z życia Jezusa Chrystusa: Dzieciństwo, Stolarz z Galileii, Portrety Syna Człowieczego, czy Opowiadania Jezusa. Osobiste studio artystyczne prowadzi w Redmond w stanie Utah, a prace malarskie często wystawia w Muzeum Sztuki w Springville 5 .

Choć przygoda artysty z rysowaniem zaczęła się w dzieciństwie, to w większości młodzieńczych lat interesował się muzyką, co dostrzegli jego rodzice. W związku z jego talentem w wieku dziewięciu lat rozpoczął prywatne lekcje gry na pianinie oraz waltorni. Był to czas kształtowania się jego dyscypliny i rozumienia sztuki, co pozwoliło przyszłemu artyście nabrać do niej szacunku. Jednak $\mathrm{w}$ wieku trzynastu lat poprosił rodziców o przerwanie lekcji muzyki i zamienienie ich na lekcje sztuki malarskiej. I tak od około 14 roku życia miał prywatnego nauczyciela i brał lekcje sztuki w szkole średniej razem z Claytonem Williamsem, a później na studiach w Brigham Young University ${ }^{6}$. Ze względu na swoją przynależność religijną do Kościoła Jezusa Chrystusa Swiętych w Dniach Ostatnich, w wieku 19 lat wyjechał na dwa lata do Rzymu? wicie wpłynął na jego przyszłą twórczość (architektura antyczna i nowożytna, rzeźby, malarstwo, sztuka figuralna $)^{8}$. Zainspirowały go kolory Italii: stonowane brązy

mit Bildern von Sieger Köde, Schwabenverlag 2004; G. Widmann, Die Bilder der Bibel von Sieger Köder. Erschließende und meditative Texte, Ostfildern 2006.

${ }^{3}$ Nazwa „mormoni” nie jest oficjalną nazwą, lecz jedynie określeniem potocznym. Pochodzi ono od Mormona, proroka-kronikarza, który według wyznawców streścił obszerne zapisy ludów zamieszkujących w dawnych czasach kontynenty amerykańskie. Księga Mormona zaistniała według mormonów drogą objawienia, a przetłumaczona przez uważanego przez nich za proroka Josepha Smitha, Jr. Miał on doznać objawienia, w którym poinstruowano go o odrzuceniu przez Boga wszystkich ówczesnych Kościołów. Księga Mormona ukazała się drukiem w 1830 r. Mormoni, uważający się za chrześcijan, po części są z nimi zbieżni, ale jest też dużo różnic. Świętymi pismami Mormonów są: Księga Mormona, Nauka i Przymierza, Perta Wielkiej Wartości, Biblia. Zob. S. Koza, Mormoni, w: Encyklopedia Katolicka, t. 13, Lublin 2009, kol. 301-304.

${ }^{4} \mathrm{~W}$ większości tworzy dla różnych środowisk chrześcijańskich. Najwięcej wytworzył dzieł dla potrzeb środowiska protestanckiego.

${ }^{5}$ B. Crowder, J. Kirk Richards, w: Mormon artist covering the Latter-day Saint arts world, nr. 1 (2008), Brigham 2008, s. 11-20.

${ }^{6}$ Kirk studiował z takimi artystami jak: Bruce Smith, Hagen Haltern, Gary Barton, James Christensen, Wulf Barsch, Joe Ostraff. Zob. Crowder, J. Kirk Richards, s. 11-12.

${ }^{7}$ Każdy mężczyzna ukończywszy 19 lat ma za zadanie odbyć dwuletnią służbę misjonarską.

${ }^{8}$ J. Kirk Richards często udawał się ze współbraćmi do muzeów m.in. Muzeum Watykańskiego w Rzymie, zwiedzali bazyliki i kościoły, w których podziwiali „niesamowite obrazy, jak malowidła Caravaggia". Wyjeżdżali również do mniejszych miast, by patrzeć na kulturę lokalną i sztukę. Crowder, J. Kirk Richards, s. 12. 
i wiele kolorów czerwieni oraz odcienie rdzy. Przyczyniło się to do zharmonizowania przyszłej palety artysty. Po powrocie nadal uczęszczał na studia w Brigham Young University i ukończył je w 2000 r. z tytułem naukowym sztuk wizualnych'.

J. Kirk Richards zachowuje w obrazach realizm i symbolizm, utrzymując jednocześnie sens obu płaszczyzn. Uwielbia malować opowiadania biblijne, bo jak sam twierdzi: „opowiadanie jest dla mnie punktem wyjścia do jego zrozumienia, zaś punkt jego wypełnienia jest w obrazie". Głównym źródłem inspiracji dla Richardsa są Biblia, ale też Księga Mormona, Nauki i Przymierza. ${ }^{10}$

W swoich dziełach nawiązuje do twórczości ulubionego artysty Carla Heinricha Blocha ${ }^{11}$, duńskiego malarza z XIX wieku ${ }^{12}$. Główną przyczyną fascynacji malarstwem Blocha są pojawiające się motywy chrześcijańskie, które ściśle wiążą się z wykładnią wiary. Kiedy zestawia się ze sobą dzieła obu artystów, z łatwością zauważa się podobieństwo tematów i przedstawień. Tematyka obrazów Richardsa opiera się głównie na kanwie chrześcijańskiej, połączonej z elementami judaizmu. Wykorzystuje do tego opowieści biblijne, sceny z życia Jezusa i przypowieści zawarte $\mathrm{w}$ Ewangeliach (il 1-3) ${ }^{13}$. Ich treść zdominowała w niemalże całości jego tematykę dzieł. Samą treść Ewangelii artysta traktuje jako mistyczne odkrywanie siebie i Boga. Kirk mówi:

Możemy rzucić na nią okiem, czytać pilnie, nieważne jakbyśmy chcieli ją zrozumieć, to nie zawsze jako ludzie jesteśmy w stanie zrozumieć ją w pełni. Zawsze będzie pewną tajemnicą. Jedynie dzięki Biblii wiemy, że Bóg istnieje, lecz nie wiemy jak dokładnie działa, ale mimo to wiemy, że jest realny.

Artysta stwierdza również, że piękno zawarte w przypowieściach Ewangelii jest doskonałym materiałem, aby przełożyć je na język malarski. Jednocześnie dostrzega strefę ekstremalną przypowieści pomiędzy tym, co dosłowne, a tym co jest przenośnią. Sam stwierdza, że jest to trudne do uchwycenia ale jest możliwe dzięki lekturze i kontemplacji tekstu Biblii. Dla Richardsa Ewangelia według św. Łukasza i św. Jana jest autobiografią Jezusa Chrystusa ${ }^{14}$.

${ }^{9} \mathrm{http}: / /$ www.jkirkrichards.com/bio.html (dostęp: 04.05.2017).

${ }^{10}$ Tamże, s. 14. Zob. Księga Mormona Przewodnik do samodzielnego studiowania dla uczniów seminarium, thum. z: Book of Mormon Study Guide for Home-Study Seminary Students, Salt Lake City 2012.

${ }^{11}$ Carl Heinrich Bloch (1834-1890). Urodził się i wychował w rodzinie luterańskiej. Praktykował swoją wiarę przez całe życie. Po odkryciu i pasji do sztuki w młodości, Bloch uczestniczył w prestiżowej Royal Danish Academy of Art w Kopenhadze. Choć był praktykującym chrześcijaninem, to dopiero w późniejszym okresie działalności artystycznej zaczął malować Jezusa Chrystusa. Ponieważ jego prace zyskały duża sławę, zlecono Blochowi namalowanie dwudziestu trzech przedstawień życia Zbawiciela na zamku w Frederiksborg. Później, na zlecenie różnych kongregacji w Danii i Szwecji, tworzył ołtarze. Zob. C. Bloch, Life of Christ: The Art of Carl Bloch, w: The Master's Hand: the Art of Carl Heinrich Bloch, red. Jay M. Todd, D.C. Pheysey, R. Neitzel Holzapfel, Salt Lake City 2010, s. 87.

${ }^{12}$ Mormoni w XIX wieku chętnie sięgali do twórczości C. Blocha, (ze względu na ukazywanie Ewangelii w obrazach-dzieje z życia Jezusa) głównie z kolekcji Frederiksborg Palace. Pomagało im to w nauczaniu Biblii i w wychowaniu religijnym.

${ }^{13}$ Crowder, J. Kirk Richards, s. 15.

${ }^{14}$ Tamże, s. 16. 
Jednym z wątków, jaki przeplata się w tematyce obrazów J.K. Richardsa jest „Boże oblicze” ukazywane na różny sposób. Od realistycznego, przez naturalistyczny, symboliczny, romantyczny, aż do abstrakcyjnego. Aby je odczytać, jak mówi artysta, potrzeba czytać i rozważać tekst święty i patrzeć na obraz. Ma to pomóc wejść w tajemnicę Boskiego życia, by choć po części zrozumieć przesłanie Ewangelii.

Pierwszym przykładem ukazania oblicza Boga jest obraz Breathe of life (Tchnienie życia). Obraz ten powstał w $2011 \mathrm{r}$. i ujęty jest $\mathrm{w}$ formie stojącego prostokąta. Utrzymany jest w wąskiej kolorystyce żółci kadmowej i żółci cynkowej, z kontrastowany różnymi odcieniami sieny i ciemnego błękitu. Dzieło przedstawia moment ożywienia nagiego Adama - pierwszego człowieka (il. 5), którego widoczna po lewej stronie obrazu postać wyłania się z prochu ziemi. Boże tchnienie posyłane jest od stojącego nad nim Boga Ojca, wyciągającego swoje ręce, szczególnie prawicę. Tym gestem niejako podnosi go ku górze i zaprasza do życia. Tchnienie życia Bożego (hebr. niszmat-hajjim) porusza (zakreślając okrąg) nie tylko Adama, ale i cały proch ziemi unoszący się w tumanach pyłu, zasłaniając przebijające się światło już stworzonego słońca. Na drugim planie, obok Ojca Niebieskiego, unosi się w powietrzu postać kobiety, zawiniętej w rozwiane szaty, nazwanej przez autora Matką Niebieską. Autor w ten sposób nawiązuje do jednej z mormońskich doktryn, w której to świat stanowi bliski związek między Bogiem a przyrodą. Owocem tego jest połączenie Jego z pierwiastkiem męskim i żeńskim. Początek człowiekowi daje Ojciec Niebieski i Matka Niebieska (odwołanie się do małżeństwa i rodziny). Bóg daje początek rodzinie. Jest to równocześnie zaproszenie człowieka do małżeństwa, które dobrze przeżyte ma osiągnąć cel chwały niebieskiej i być małżeństwem na wieczność ${ }^{15}$.

Do namalowania obrazu Kirk posłużył się pierwszym i drugim opisem stworzenia człowieka zawartym w Piśmie Świętym:

A wreszcie rzekł Bóg: «Uczyńmy człowieka na Nasz obraz, podobnego Nam. Niech panuje nad rybami morskimi, nad ptactwem powietrznym, nad bydłem, nad ziemią i nad wszystkimi zwierzętami pełzającymi po ziemi!» Stworzyl więc Bóg czlowieka na swój obraz, na obraz Boży go stworzyl: stworzył mężczyznę i niewiastę. (Rdz 1, 6-7) ${ }^{16}$ (...) Gdy Pan Bóg uczynił ziemię i niebo, nie było jeszcze żadnego krzewu polnego na ziemi, ani żadna trawa polna jeszcze nie wzeszła - bo Pan Bóg nie zsyłał deszczu na ziemię i nie było człowieka, który by uprawiał ziemię i rów kopał w ziemi, aby w ten sposób nawadniać całą powierzchnię gleby - wtedy to Pan Bóg ulepil czlowieka z prochu ziemi i tchnąl w jego nozdrza tchnienie życia, wskutek czego stał się czlowiek istotą żywą. (Rdz 2, 5-6).

Na obrazie widać już nie tylko sam moment tchnienia, ale jego skutek, bo człowiek stał się istotą żywą. Efekt ruchu prochu ziemi podkreśla nie tylko kolorystyka, ale też zamalowane farbą w formie impastu, grudki ziemi. Autor w przedstawianym obrazie zwraca uwagę na treści zawarte w Piśmie Świętym, które (jak

${ }^{15}$ B. McConkie, Mormon Doctrine, Salt Lake City1979, s. 345-346.

${ }^{16}$ Wszystkie teksty biblijne zaczerpnięte są z Pisma Świętego Starego i Nowego Testamentu w przekładzie z języków oryginalnych, Pallotinum, wydanie piąte, Poznań 2005. 
sam zauważa) w sposób wyjątkowy pozwalają każdemu człowiekowi uczynić wgląd na odwieczny plan Boga ${ }^{17}$, że człowiek jest stworzony na obraz Boży i Jego podobieństwo. Na obrazie podkreśla to kilka cech: ta sama kolorystyka postaci, połączenie osoby Boga i Adama z ziemią, ciało Adama i odsłonięte ramię ojca Niebieskiego. Przedstawienie sugeruje, że człowiek może stać się jak Bóg. Na końcu czasów, ludzie mogą osiągnąć pełnię boskości, gdyż jak wierzą mormoni wszyscy są dosłownymi córkami i synami Boga. Obraz wskazuje na pokrewieństwo człowieka z Bogiem objawiające się w akcie stworzenia. Widz rozważający tekst Biblii i patrząc na namalowaną scenę stworzenia pierwszego człowieka, jest skonfrontowany z rzeczywistością, którą przedstawia obraz. Perspektywa obrazu „umieszcza” go niejako w ziemi, z której jest „wezwany do życia”.

Kolejnym przykładem przedstawienia oblicza Boga jest obraz Paralityc (Paralityk), namalowany w 2001 r. techniką olejną na desce (il. 4). Utrzymany w kolorystyce ciemnego granatu, brązu i fioletu, skontrastowany jest błękitem nieba, czerwienią obicia krzesła Jezusa i światłem słońca. Przedstawia scenę uzdrowienia paralityka, a dokładniej sam moment opuszczania go przed oblicze Jezusa:

Pewnego dnia, gdy Jezus nauczał, siedzieli przy tym faryzeusze i uczeni w Prawie, którzy przyszli ze wszystkich miejscowości Galilei, Judei i Jerozolimy. A była w Nim moc Pańska, że mógł uzdrawiać. Wtem jacyś ludzie niosąc na łożu człowieka, który był sparaliżowany, starali się go wnieść i położyć przed Nim. Nie mogąc z powodu thumu w żaden sposób go przynieść, wyszli na płaski dach i przez powałę spuścili go wraz z lożem w sam środek przed Jezusa. On widząc ich wiarę rzekł: Człowieku, odpuszczają ci się twoje grzechy. Na to uczeni w Piśmie i faryzeusze poczęli się zastanawiać i mówić. Któż On jest, że śmie mówić bluźnierstwa? Któż może odpuszczać grzechy prócz samego Boga? Lecz Jezus przejrzał ich myśli i rzekł do nich: Co za myśli nurtują w sercach waszych? Cóż jest łatwiej powiedzieć: Odpuszczają ci się twoje grzechy, czy powiedzieć: Wstań i chodź? Lecz abyście wiedzieli, że Syn Człowieczy ma na ziemi władzę odpuszczania grzechów - rzekł do sparaliżowanego: Mówię ci, wstań, weź swoje łoże i idź do domu! I natychmiast wstał wobec nich, wziął łoże, na którym leżał, i poszedł do domu, wielbiąc Boga. Wtedy zdumienie ogarnęło wszystkich; wielbili Boga i pełni bojaźni mówili: przedziwne rzeczy widzieliśmy dzisiaj. (Łk 5,17-26)

Akcja, jak redaguje Ewangelia według św. Łukasza, rozgrywa się w domu wypełnionym i otoczonym zgromadzonym ludem (jedna linia dalej). Tylko jedna z postaci, kobieta będąca wewnątrz domu, przedstawiona w prawej dolnej części

${ }^{17} \mathrm{~W}$ nauczaniu mormonów życie ludzkie nie rozpoczęło się w momencie narodzin i nie skończy się w chwili śmierci. Przed narodzeniem duch człowieka przebywał z Ojcem Niebieskim, który stworzył człowieka. To radosny okres, w którym duch uczy się o Boskim planie szczęścia i o tym, jak osiągnąć prawdziwą radość. Jednym z najważniejszych warunków otrzymania chwały celestialnej jest małżeństwo na wieczność. Mormoni poślubiają swoich małżonków w specjalnie budowanych do tych celów świątyniach. Wierzą, że ten związek między mężem a żoną (oraz przyszłymi dziećmi) będzie trwał nie tylko do śmierci jednego ze współmałżonków, ale jeżeli oboje dochowają wierności (sobie nawzajem oraz Bogu i jego przykazaniom), to ich małżeństwo i rodzina będą trwały przez całą wieczność. Mormoni kładą duży nacisk na szczęście rodzinne. Mają też zazwyczaj wielodzietne rodziny. J. Smith, Teachings of the Prophet, Salt Lake City 1938, s. 345-346n. 
obrazu, spogląda na widza zapraszając go do bycia świadkiem tego, co za chwilę sie wydarzy. Postać Jezusa utrzymuje kontakt wzrokowy z paralitykiem, który mimo swej ułomności próbuje zbliżyć wykrzywioną dłoń do ręki Zbawiciela. Widać tu nawiązanie do gestu wyciągniętej ręki Boga Ojca do Adama z Kaplicy Sykstyńskiej.

Aby skoncentrować uwagę na Chrystusie i paralityku, artysta posłużył się światłem słońca wpadającym przez otwór w dachu. Oświeca ono postać Zbawiciela oraz twarz i ręce chorego. Jezus $w$ tym momencie jest całkowicie zainteresowany osobą chromego, bo wie, że potrzebuje on nie tylko uzdrowienia fizycznego, ale i uwolnienia z niemocy grzechu, który jak wierzą Judejczycy, jest przyczyną choroby (por. Łk 5,19-26; J 9). Oblicze Syna Bożego jest spokojne. Właściwie w całej scenie dochodzi do spotkania dwóch osób: Mistrza z Nazaretu - uzdrowiciela z człowiekiem doświadczonym paraliżem. Czyli Moc z niemocą, Bóg z człowiekiem. Malarz dokonuje tego zabiegu w celu wywołania w widzu osobistych uczuć i rozpoznania tych, jakie żywi obecnie do Chrystusa. Patrząc się na ten obraz, widz jest zaproszony do poszukiwania w sobie pragnienia względem Zbawiciela ${ }^{18}$.

Następnym medytacyjnym przykładem ukazania oblicza Boga jest obraz Nicodemus (Nikodem) z 2006 r. (il. 6). Wykonując to dzieło, artysta sięgnął do trzeciego rozdziału Ewangelii według św. Jana ${ }^{19}$. Spotkanie Nikodema z Jezusem

${ }^{18}$ Artysta chce tak przedstawiać Jezusa aby wywoływało to uczucia i pragnienia jakie żywimy względem Zbawiciela. Patrząc na wizerunek mamy widzieć, że jest sprawiedliwy, w rzeczy samej jedyny, pełen miłosierdzia kochający, potężny wszechwiedzący, sprawiedliwy. Zob. Crowder, J. Kirk Richards, s. 16.

${ }^{19}$ Był wśród faryzeuszów pewien człowiek, imieniem Nikodem, dostojnik żydowski. Ten przyszedł do Niego nocą i powiedział Mu: «Rabbi, wiemy, że od Boga przyszedłeś jako nauczyciel. Nikt bowiem nie mógłby czynić takich znaków, jakie Ty czynisz, gdyby Bóg nie był z Nim». W odpowiedzi rzekł do niego Jezus: «Zaprawdę, zaprawdę, powiadam ci, jeśli się ktoś nie narodzi powtórnie, nie może ujrzeć królestwa Bożego». Nikodem powiedział do Niego: «Jakżeż może się człowiek narodzić będąc starcem? Czyż może powtórnie wejść do łona swej matki i narodzić się?» Jezus odpowiedział: «Zaprawdę, zaprawdę, powiadam ci, jeśli się ktoś nie narodzi z wody i z Ducha, nie może wejść do królestwa Bożego. To, co się z ciała narodziło, jest ciałem, a to, co się z Ducha narodziło, jest duchem. Nie dziw się, że powiedziałem ci: Trzeba wam się powtórnie narodzić. Wiatr wieje tam, gdzie chce, i szum jego słyszysz, lecz nie wiesz, skąd przychodzi i dokąd podąża. Tak jest z każdym, który narodził się z Ducha». W odpowiedzi rzekł do Niego Nikodem: «Jakżeż to się może stać?» Odpowiadając na to rzekł mu Jezus: «Ty jesteś nauczycielem Izraela, a tego nie wiesz? Zaprawdę, zaprawdę, powiadam ci, że to mówimy, co wiemy, i o tym świadczymy, cośmy widzieli, a świadectwa naszego nie przyjmujecie. Jeżeli wam mówię o tym, co jest ziemskie, a nie wierzycie, to jakżeż uwierzycie temu, co wam powiem o sprawach niebieskich? I nikt nie wstąpił do nieba, oprócz Tego, który z nieba zstąpił - Syna Człowieczego. A jak Mojżesz wywyższył węża na pustyni, tak potrzeba, by wywyższono Syna Człowieczego, aby każdy, kto w Niego wierzy, miał życie wieczne. Tak bowiem Bóg umiłował świat, że Syna swego Jednorodzonego dał, aby każdy, kto w Niego wierzy, nie zginął, ale miał życie wieczne. Albowiem Bóg nie posłał swego Syna na świat po to, aby świat potępił, ale po to, by świat został przez Niego zbawiony. Kto wierzy w Niego, nie podlega potępieniu; a kto nie wierzy, już został potępiony, bo nie uwierzył w imię Jednorodzonego Syna Bożego. A sąd polega na tym, że światło przyszło na świat, lecz ludzie bardziej umiłowali ciemność aniżeli światło: bo złe były ich uczynki. Każdy bowiem, kto się dopuszcza nieprawo- 
ujęte jest kadrem fotograficznym, wykonanym z ukrycia. Nikodem siedzi przy niewielkim okrągłym stoliku $\mathrm{z}$ rękami wyciągniętymi nad lampą oliwną, w geście ogrzewania dłoni. Jednocześnie kieruje swoje spojrzenie i uwagę na Mistrza z Nazaretu. Chrystus stoi patrząc na Nikodema, prawą ręką wskazuje na gliniany kubek, po którego sięga lewą dłonią. Szaty Mistrza są świetliste i biją dużym blaskiem - to on jest źródłem światła ${ }^{20}$. Na pierwszym planie w cieniu stoją gliniane naczynia. Pomimo rozłożonych kilku lampek oliwnych w pomieszczeniu, postać Jezusa oświetla najbardziej pomieszczenie. Artysta uchwycił moment konkluzji rozmowy faryzeusza $\mathrm{z}$ Jezusem:

A sąd polega na tym, że światło przyszło na świat, lecz ludzie bardziej umiłowali ciemność aniżeli światło: bo złe były ich uczynki. Każdy bowiem, kto się dopuszcza nieprawości, nienawidzi światła i nie zbliża się do światła, aby nie potępiono jego uczynków. Kto spełnia wymagania prawdy, zbliża się do światła, aby się okazało, że jego uczynki są dokonane w Bogu. (J 3,1-21)

Naczynia: dzbany i kubek nawiązują do Wody Żywej, którą Zbawiciel chce zaoferować człowiekowi. Tak jak dzbany „oczekują napełnienia” by mogły funkcjonować według przeznaczenia, tak człowiek „oczekuje napełnienia się”, potrzebuje „narodzić się z wody i z Ducha”, by mógł być zdolnym by wejść do królestwa Bożego. Oblicze Chrystusa jest obliczem sędziego, lecz nie z dnia sądu ostatecznego, ale tego, który na drzewie krzyża rozprawi się z grzechem i śmiercią. Będzie to triumf sądu miłości nad nienawiścią. Symbolika światła i ciemności w obrazie nie jest bez znaczenia. Chrystus jako „światłość świata”, jest tym, który oświeca ciemności serca umysłu pragnień. Przed tym światłem człowiek się nie ukryje, ,wszystko odkryte i odsłonięte jest przed oczami Tego, któremu musimy zdać rachunek" (Hbr 4,13). Ono pozwala człowiekowi stanąć w prawdzie o sobie samym, bo dopiero przy Chrystusie człowiek odkrywa, właściwie kim jest.

Ostatnim przykładem obrazowania oblicza Boga według K. Richardsa jest obraz pod tytułem The lost coin (Zagubiona drahma) powstały w 2006 r. (il. 7). Artysta odtwarza niejako opowiadanie Jezusa w sposób wyobrażenia, przenosząc widza w czasie:

Albo jeśli jakaś kobieta, mając dziesięć drachm, zgubi jedną drachmę, czyż nie zapala światła, nie wymiata domu i nie szuka starannie, aż ją znajdzie? A znalazłszy ją, sprasza przyjaciółki i sąsiadki i mówi: «Cieszcie się ze mną, bo znalazłam drachmę, którą zgubiłam». Tak samo, powiadam wam, radość powstaje u aniołów Bożych z jednego grzesznika, który się nawraca. (Łk 15, 8)

Ujęcie sceny wykracza poza ramy obrazu. Kolejny raz artysta posługuje się kadrem fotograficznym. Widzimy postać klęczącej kobiety w momencie przerwania poszukiwania zagubionej drachmy. W prawej dłoni trzyma zapaloną świecę w kaganku, zaś w lewej miotłę. Głowę i spojrzenie kieruje w stronę oglądającego

ści, nienawidzi światła i nie zbliża się do światła, aby nie potępiono jego uczynków. Kto spełnia wymagania prawdy, zbliża się do światła, aby się okazało, że jego uczynki są dokonane w Bogu». (J 3,1-21)

${ }^{20}$ Artysta pokazując Chrystusa w świetle, nawiązuje również do ukazania jego jako Pana, który króluje od wieków. Crowder, J. Kirk Richards, s. 16-17. 
obraz. Połączenie fioletów z sieną paloną i granatem pozwoliły artyście odtworzyć klimat nocy. Mimo, że za otwartymi drzwiami domu i oknem widać dopiero co wyłaniający sie blask poranka, to tylko światło świecy wydobywa z ciemności postać kobiety. Na obrazie nie widzimy nerwowego czy gwałtownego zachowania. Na twarzy maluje się spokój, co podkreśla biały, delikatnie opadający na ramiona welon. Spojrzenie skierowane w stronę widza i otwarte lekko usta zdradzają, że coś zobaczyła. Znalazła swoją zgubę. Tą zgubioną i tak szukaną drachmą jest widz, który patrzy w oczy szukającej kobiety. W rzeczywistości, w czułej, odzwierciedlającej się w naturze kobiety miłości, autor ukazał tęskniącego za człowiekiem Boga. Namalowany fragment Ewangelii Łukasza w jest częścią tryptyku: Dobry Pasterz, Zagubiona Drahma i Mitosierny Ojciec. Bóg pragnie przeżywać pełnię szczęścia z człowiekiem, dlatego tęskni za nim, szuka go i cieszy się z odzyskania go na nowo, znalezienia tego, co zginęło. Kiedy medytujący obraz widz, odkryję te prawdę ukrytą w obrazie spostrzeże, że jest zaproszonydo wyjścia z ukrycia i zbliżenia się do tej, która go szuka.

Richards malując oblicza Boga-Chrystusa, nadaje mu ziemski wizerunek, zaś gdy maluje Zbawiciela, nadaje mu wizerunek uwielbionego. Gdy prześledzi się dotychczasowa twórczość artysty, można zauważyć, że w większości z nich nie maluje bardzo dokładnej twarzy Chrystusa ze szczegółami, gdyż jak sam uważa:

większość z nas nie ma doświadczenia widzenia Jezusa. Ale mamy doświadczenie osobiste opatrzności Bożej obecności w życiu ducha Chrystusa ${ }^{21}$. Dlatego w przedstawieniach oblicza Boga, Chrystusa, nie zajmuję się detalami i idealizacją, bo realistyczne przedstawienie jest poniekąd niebezpieczne (...) Moje malarstwo jest odpowiedzią na klasyczne malowanie Jezusa, często wyidealizowane. Malując go, wkładam wysiłek, by przedstawić jego postać, w tym, co jest dla niego najbardziej reprezentatywne ${ }^{22}$.

Na powyższym przykładzie malarstwa mormońskiego artysty J. Kirka Richardsa można zauważyć, że tematyka i sposób przedstawiania „oblicza Boga” jest dla odbiorcy bardzo absorbujący. Co więcej, przynagla do zatrzymania się nad tekstem Biblii i refleksji. Osoby chcące czytać je w kluczu artysty odkryją, że obrazy te pomagają w medytacji nad słowem natchnionym i są dopowiedzeniem tekstów Ewangelii. Natomiast katoliccy artyści może znajdą w nich podpowiedź, że do malowania obrazów do przestrzeni liturgicznej kościoła nie wystarczy tylko wyobraźnia i warsztat malarski, ale sięgnięcie do źródła jakim jest Słowo Boże.

słowa kluczowe: J. Kirk Richards; Carl Heinrich Bloch; Biblia; malarstwo sakralne; malarstwo współczesne; mormoni; realizm; symbolizm

${ }^{21}$ W nauczaniu mormonów, Duch Święty jest istotą duchową obecną pośród ludzi, zaś Jezus Chrystus to fizyczny Syn Boga i powróci cieleśnie na ziemię, aby zapoczątkować tysiącletnie królestwo.

${ }^{22} \mathrm{http} / / /$ mormonartist.net/interviews/j-kirk-richards-2013/ (dostęp: 01.06.2015). 


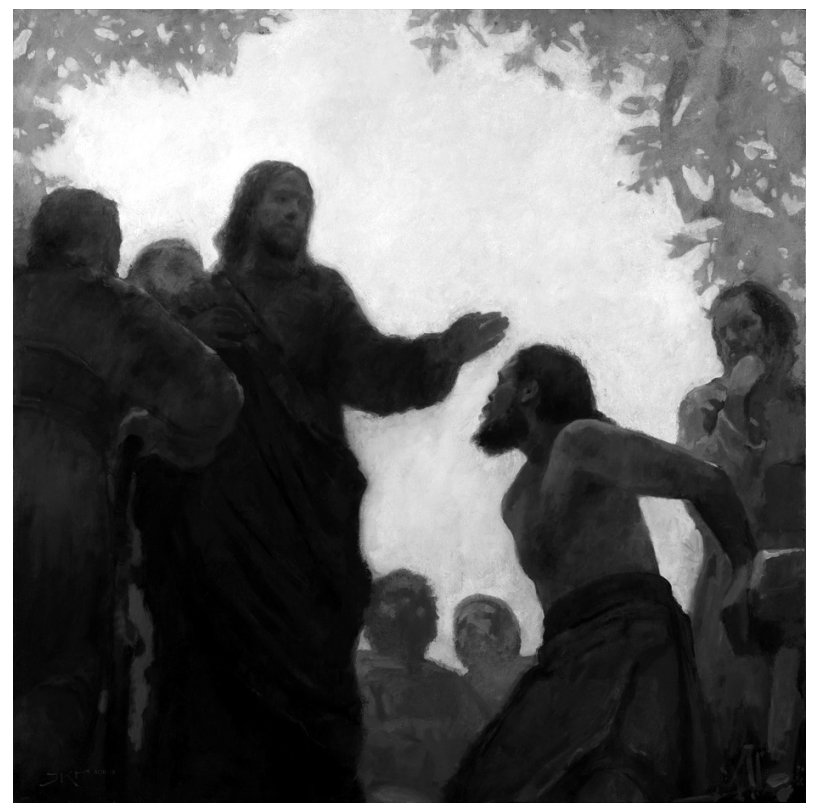

1. J. Kirk Richards, Sight restored (Przywrócony wzrok), 2004, olej na płótnie, $91 \times 91 \mathrm{~cm}$.

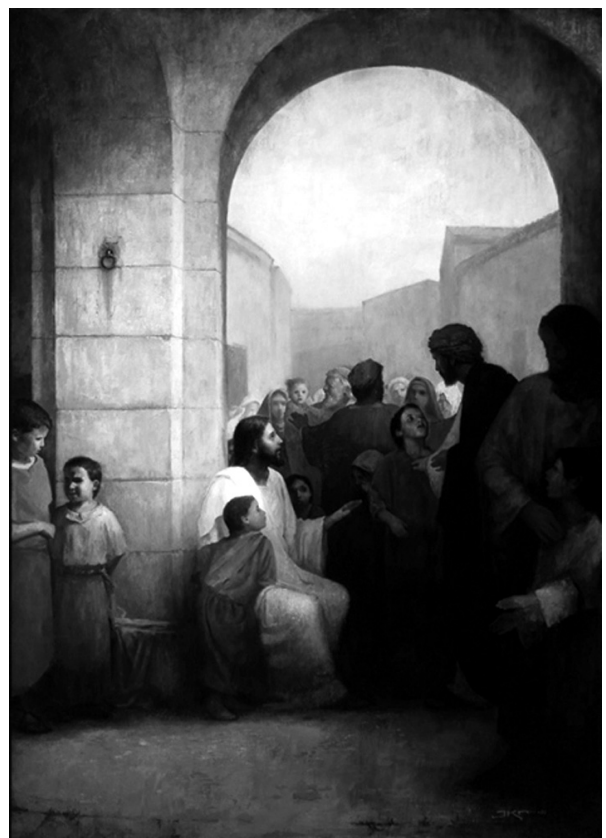

2. J. Kirk Richards, Suffer the Children (Ścierpieć dzieci), 2003, olej na desce, $123 \times 87 \mathrm{~cm}$. 


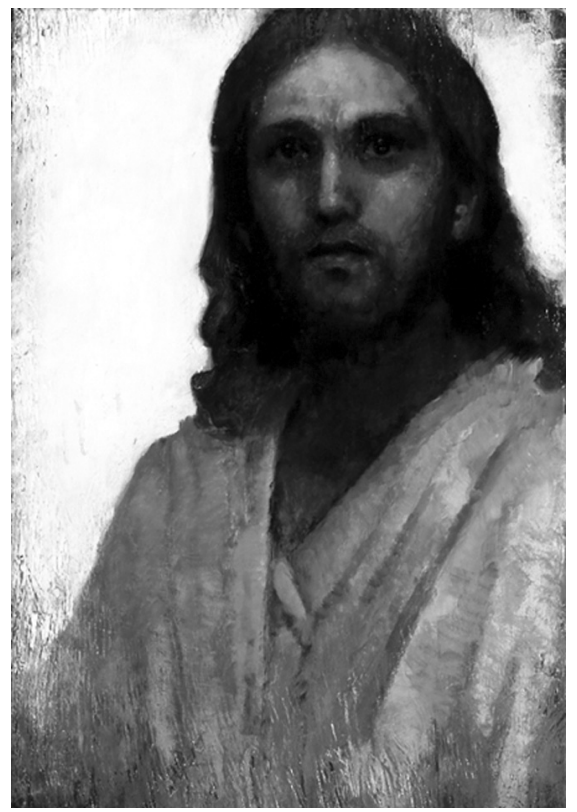

3. J. Kirk Richards, Son of man - coral (Syn Człowieczy), 2006, olej na desce $40 \times 60 \mathrm{~cm}$.

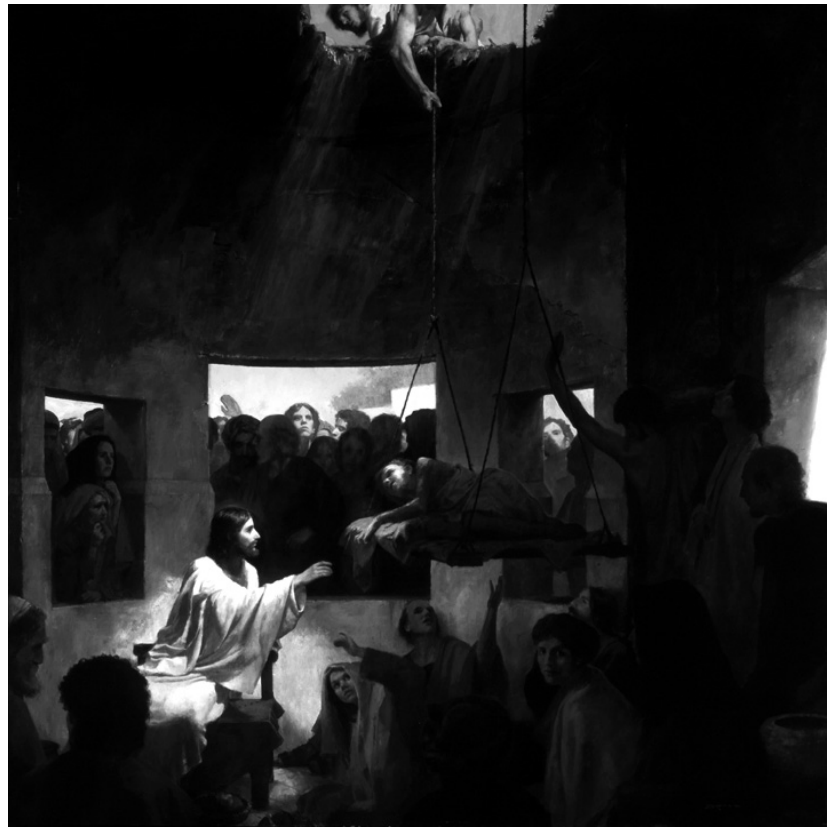

4. J. Kirk Richards, Paralityc (Paralityk), 2001, olej na desce, $122 \times 122 \mathrm{~cm}$ studio artysty w Redmond, Utah, USA. 


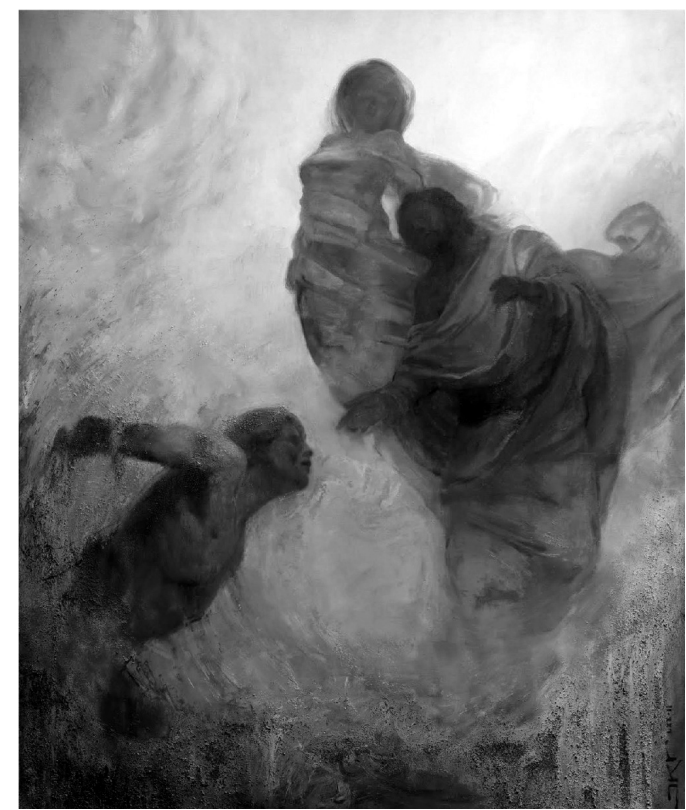

5. J. Kirk Richards, Breath of life (Tchnienie życia), 2011, olej na desce $203 \times 250 \mathrm{~cm}$, studio artysty w Redmond, Utah, USA.

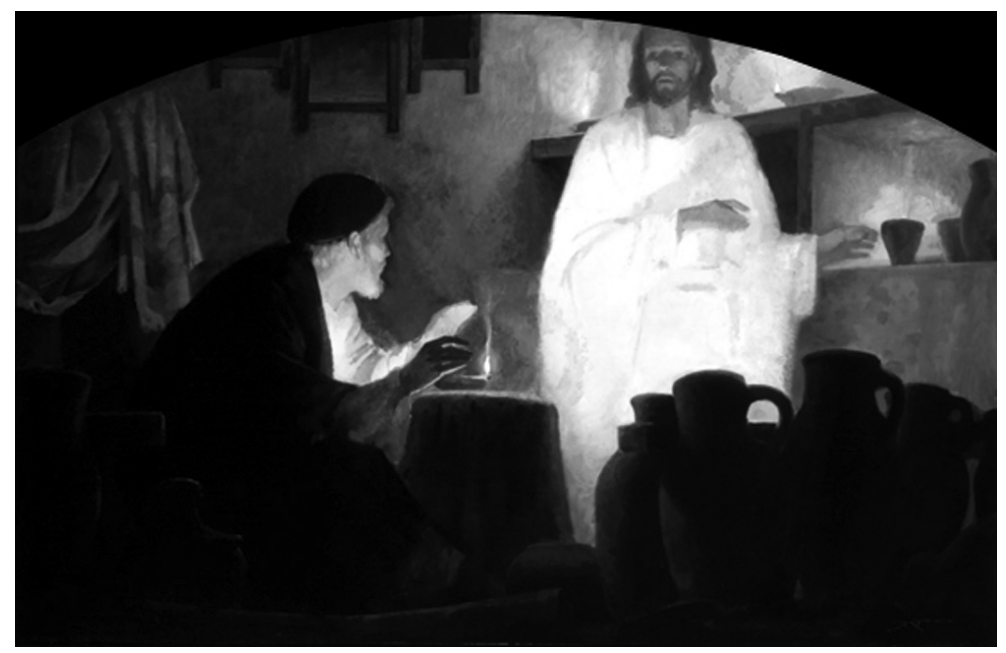

6. J. Kirk Richards, Nicodemus (Nikodem), 2006, olej na desce, 137×89 cm, studio artysty w Redmond, Utah, USA. 


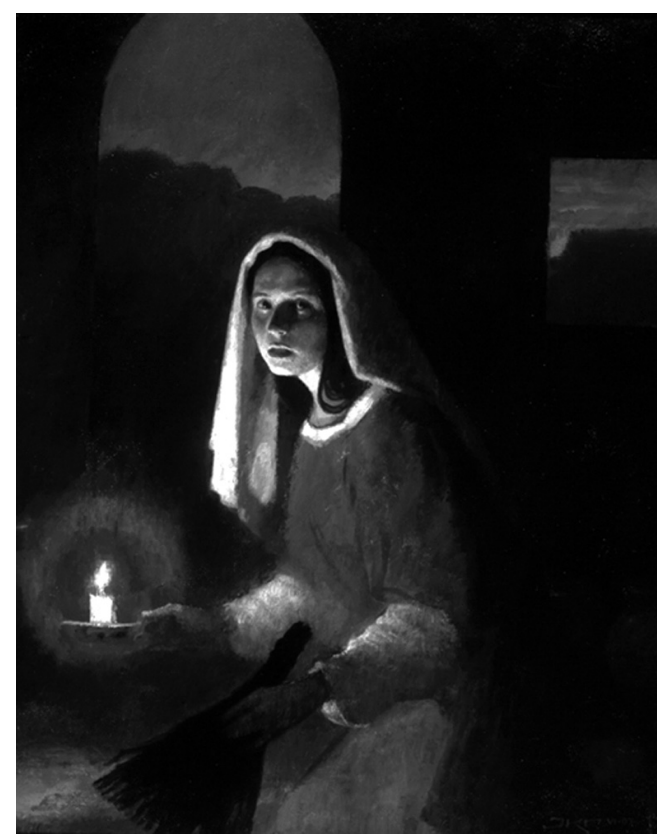

7. J. Kirk Richards, The lost coin (Zagubiona Drahma), 2003, olej na płótnie, $38 \times 50 \mathrm{~cm}$, studio artysty w Redmond, Utah, USA

\section{BIBLIOGRAFIA}

\section{Źródła}

Jan Paweł II, List apostolski Ojca Świętego Jana Pawła II do artystów. Do tych, którzy z pasja i poświęceniem poszukuja nowych ,epifanii” Piękna, aby podarować je światu w twórczości artystycznej, Wrocław 2005.

Księga Mormona. Przewodnik do samodzielnego studiowania dla uczniów seminarium, thum. z: Book of Mormon Study Guide for Home-Study Seminary Students, Salt Lake City 2012.

McConkie Bruce, Mormon Doctrine, Salt Lake City, Utah, 1979.

Pismo Święte Starego i Nowego Testamentu w przekładzie z języków oryginalnych, Pallotinum, wydanie piąte, Poznań 2005.

Wojtyła Karol, Ewangelia a sztuka. Rekolekcje dla artystów, Kraków-Rzym 2011.

\section{Opracowania}

Bloch Carl Heinrich, Life of Christ: The Art of Carl Bloch, red. Jay M. Todd 2011.

Crowder Ben, J. Kirk Richards, „Mormon artist covering the Latter-day Saint arts world”, nr 1 (2008), Brigham 2008, s. 11-20.

J. Kirk Richards, http://www.jkirkrichards.com/bio.html (dostęp: 04.05.2016).

Köder Sieger, Die Bibel mit Bildern von Sieger Köder, Schwabenverlag 2004. 
Koza Stanisław Józef, Mormoni, w: Encyklopedia Katolicka, t. 13, Lublin 2009, kol. 301304.

Mormon artists, http://mormonartist.net/interviews/j-kirk-richards-2013, (dostęp: 01.06.2015).

Pheysey Dawn, C. Neitzel Holzapfel Richard, The Master's Hand: the Art of Carl Heinrich Bloch, Salt Lake City 2010.

Ravasi Gianfranco, Rupnik Marko Ivan, Fascynacja pięknem. Miedzy Biblia a teologia, tłum. Barbara Żurowska, Kraków 2012.

Smith Joseph, Teachings of the Prophet, Salt Lake City, Utah 1938.

Widmann Gertrud, Die Bilder der Bibel von Sieger Köder. Erschließende und meditative Texte, Ostfildern 2006.

\section{MEDYTACYJNE PRZEDSTAWIENIA BOGA W TWÓRCZOŚCI J. KIRKA RI- CHARDSA}

\section{Streszczenie}

Współczesny artysta Kirk Richards, pomimo tego, że jest wyznania mormońskiego, wzorując się na twórczości Carla Heinricha Blocha, tworzy obrazy ukazujące oblicza Boga, będące wynikiem rozważania i medytacji Słowa Bożego.

Słowa kluczowe: J. Kirk Richards; Carl Heinrich Bloch; Biblia; malarstwo sakralne; malarstwo współczesne; mormoni; medytacja; realizm; symbolizm

\section{MEDITATIVE REPRESENTATIONS OF GOD IN J. KIRK RICHARD'S WORK}

\section{Summary}

Contemporary artist Kirk Richards - despite being a Mormon - while modelling on the work of Carl Heinrich Bloch, creates the pictures of the face of God, which are the result of his meditation on the Word of God.

Keywords: J. Kirk Richards; Carl Heinrich Bloch; the Bible; sacred painting; contemporary painting; the Mormons; meditation; realism; symbolism 